\title{
Gamma Ray Transmission for Hydraulic Conductivity Measurement of Undisturbed Soil Columns
}

\author{
Anderson Camargo Moreira*, Otávio Portezan Filho, Fábio Henrique Moraes Cavalcante, \\ Melayne Martins Coimbra and Carlos Roberto Appoloni \\ Departamento de Física; Universidade Estadual de Londrina; sandersoncamargo@yahoo.com.br; C. P. 6001; \\ 86051-990; Londrina - PR - Brasil
}

\begin{abstract}
This work had the objective to determine the Hydraulic Conductivity $K(\theta)$ function for different depth levels $z$, of columns of undisturbed soil, using the gamma ray transmission technique applied to the Sisson method. The results indicated a growing behavior for $K(\theta)$ and a homogeneous soil density, both in relation to the increase of the depth. The methodology of gamma ray transmission showed satisfactory results on the determination of the hydraulic conductivity in columns of undisturbed soil, besides being very reliable and a nondestructive method.
\end{abstract}

Key words: Undisturbed soil column; gamma-ray transmission; hydraulic conductivity

\section{INTRODUCTION}

The study of different types of soils, seeking the determination of its porosity and hydraulic conductivity, for example, is of extreme importance in the agriculture. For a good development of several types of crops that are directly related to the quality of the soil in which they are being cultivated, non-destructive methods are being thoroughly applied for such determinations. In the study of temporal and spatial evolution of soil water content and hydraulic conductivity, the gamma ray transmission method is an important method and is non destructive with high reliability degree in the acquired data.

The gamma ray attenuation technique in the soil physics was applied initially for bulk density measurements (Reginato and Van Bavel, 1964) and later for determination of the water content in the soil. Reichardt (1965) used the gamma ray attenuation in the Brazilian soils. In this method, an accurate measurement of the sample thickness is important to avoid erroneous results of the bulk density and water content in the soil.

Measurements accomplished in laboratory usually employ samples of disturbed and undisturbed soil packed in columns. Soil columns can be scanned by a mono or dual energy gamma beam (configuration in line, perpendicular or parallel) for the bulk density and wetting study. Some radioactive sources, gamma radiation emitting, were used in the measurements of soils, for example: ${ }^{60} \mathrm{Co}$ (Gardner and Calissendorff, 1967 and Appoloni and Rios, 1994), ${ }^{137} \mathrm{Cs}$ and ${ }^{241} \mathrm{Am}$ (Ferguson and Gardner, 1962; Corey et al., 1971; Nofziger, 1978; Souza et al., 1991; Oliveira, 1991; Vaz et al., 1992, 1994 and Portezan, 1997).

The aim of this work was to determine the hydraulic conductivity function $[K(\theta)]$ of an

Author for correspondence 
undisturbed soil column, employing the gamma ray transmission and Sisson et al. (1980) methodologies.

\section{Theoretical}

The Beer's law establishes the relationship between the attenuated radiation intensity by a target and other parameters of the system. It can be written as:

$$
I=I_{0} \exp (-\mu \rho x)
$$

where $I_{0}$ and $I$ are the incident and emergent gamma ray beam intensities respectively (cont $\mathrm{s}^{-1}$ ), $\mu$ is the mass attenuation coefficient of the target $\left(\mathrm{m}^{2} \mathrm{~kg}^{-1}\right), \rho$ is the density of the target $\left(\mathrm{kg} \mathrm{m}^{-3}\right)$ and $\mathrm{x}$ is the thickness of the target (m).

The linear attenuation coefficient of the soil, $\mu_{\mathrm{s}} \rho_{\mathrm{s}}\left(\mathrm{m}^{-1}\right)$ was calculated using the following equation:

$\mu_{s} \rho_{s}=\frac{1}{x} \ln \frac{I_{v}}{I_{s}}-\mu_{w} \theta_{0}$

where $I_{v}$ is the emergent gamma ray beam intensity of the empty container ( $\operatorname{cont} \mathrm{s}^{-1}$ ), $\mathrm{I}_{\mathrm{s}}$ is the emergent gamma ray beam intensity of the container with soil (cont $\left.\mathrm{s}^{-1}\right), \mu_{\mathrm{W}}$ is the water mass attenuation coefficient $\left(\mathrm{m}^{2} \mathrm{~kg}^{-1}\right)$ and $\theta_{0}$ is the initial volumetric water content $\left(\mathrm{m}^{3} \mathrm{~m}^{-3}\right)$. Knowing the soil bulk density, $\rho_{\mathrm{s}}$ and using Equation (2), the soil mass attenuation coefficient $\mu_{\mathrm{s}}$ was calculated.

The water content profiles as a function of time, $\theta(z, t)$, were obtained using the equation below:

$$
\theta(z, t)=\frac{1}{\mu_{w}}\left[\frac{1}{x} \ln \frac{I_{c v}}{I}-\mu_{s} \rho_{s}\right]
$$

where $I_{c v}$ is the emergent gamma ray beam intensity of the empty column ( $\left.\operatorname{cont~} \mathrm{s}^{-1}\right)$ and $\mathrm{I}$ is the emergent gamma ray beam intensity of the soil column with volumetric water content $\theta$ (cont $\left.\mathrm{s}^{-1}\right)$.
Sisson et al. (1980) presents their methodology for determination of the hydraulic conductivity function, using the following equation.

$\ln \left(\frac{L}{t}\right)=\ln (\gamma K s)+\gamma\left(\theta-\theta_{s}\right)$

Using the linear regression fit $\ln (\mathrm{L} / \mathrm{t})$ versus $\left(\theta-\theta_{\mathrm{s}}\right)$ for each depth $\mathrm{L}$, the constant values $\mathrm{K}_{\mathrm{S}}$ and $\gamma$ can be determined. $\gamma$ is the value of the inclination and $\mathrm{K}_{\mathrm{S}}$ is calculated using the linear coefficient of Equation (4). By substituting these constants in the exponential relationship for the hydraulic conductivity, also used by Hillel et al. (1972), Libardi et al. (1980), Falleiros et al. (1998), the exponential relationship between the conductivity $K(\theta)$ and the water content $\theta$ for each depth can be written as:

$K(\theta)=K s \exp \gamma\left[\left(\theta-\theta_{s}\right)\right]$

where $\mathrm{K}(\theta)$ is the hydraulic conductivity $\left(\mathrm{m} \mathrm{s}^{-}\right.$ $\left.{ }^{1}\right), \theta$ is the volumetric water content $\left(\mathrm{m}^{3} \mathrm{~m}^{-3}\right)$ and $\theta_{\mathrm{s}}$ is the saturation volumetric water content $\left(\mathrm{m}^{3}\right.$ $\mathrm{m}^{-3}$ ). In Portezan (1997), the value for $\theta_{\mathrm{s}}$ was extrapolated from the experimental data of the measured volumetric water content, during the water redistribution in the soil column.

\section{MATERIALS AND METHODS}

In the measurements using the gamma ray, transmission method was used a 2" 2 2" diameter $\mathrm{NaI}$ ( $\mathrm{Tl}$ ) scintillation detector coupled to a standard gamma spectrometry electronics, a $3.7 \mathrm{x}$ $10^{9} \mathrm{~Bq}^{241} \mathrm{Am}$ gamma ray source with $59.6 \mathrm{keV}$, a $2 \times 10^{-3} \mathrm{~m}$ diameter source collimator and a $5 \times 10^{-}$ ${ }^{3} \mathrm{~m}$ diameter detector collimator. Fig. 1 shows a diagram of the electronics used in the measurements.

Fig. 2 shows the experimental set-up used to perform the water infiltration and redistribution measurements in soil column. The measurement table allows vertical movement of the column. 


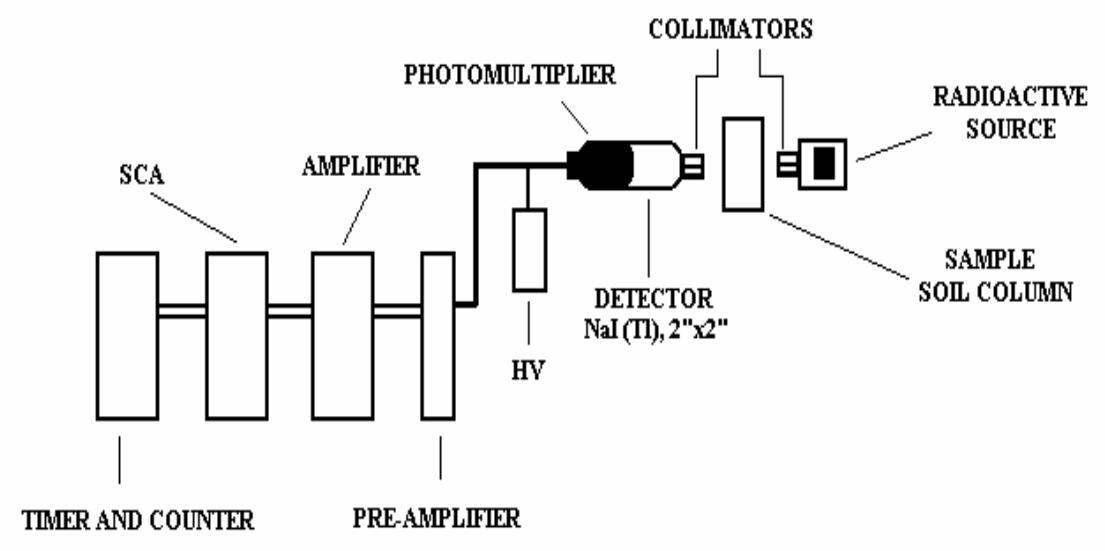

Figure 1 - Gamma Ray Spectrometry Standard Electronics Diagram.

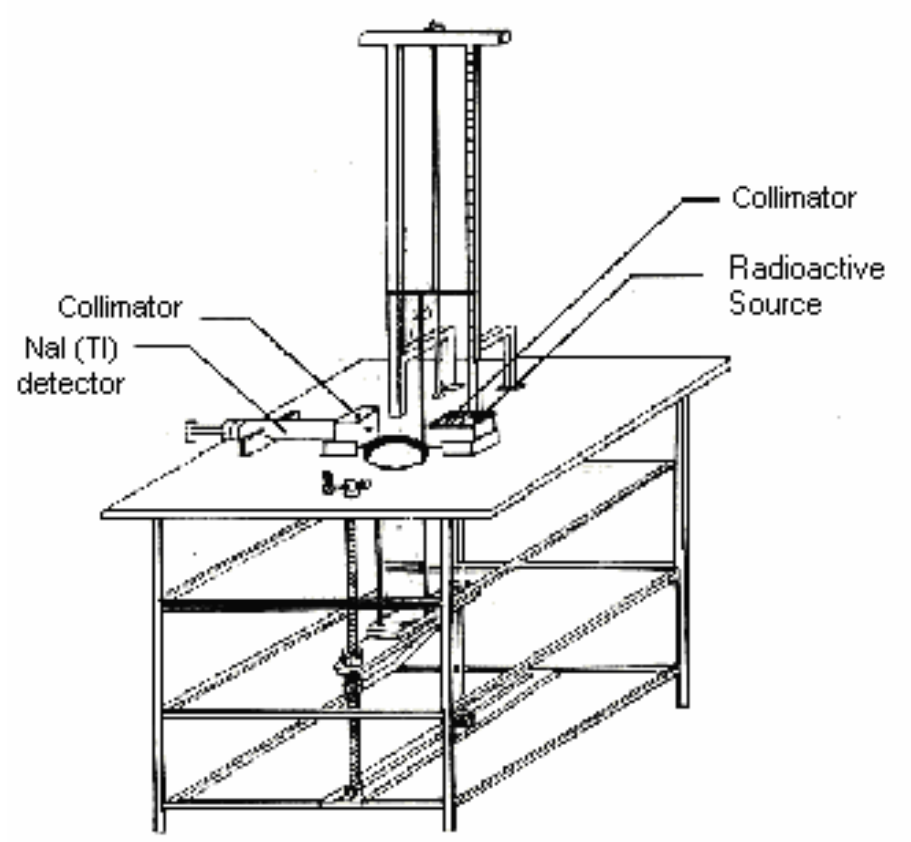

Figure 2 - Experimental Set-up Diagram.

Initially, the water and soil mass attenuation coefficients were measured with the gamma ray transmission method. An acrylic box was used to hold water or soil. The initial volumetric water content $\theta_{0}$ was determined using the gravimetric method. The soil column LRd (dystrophic dark red soil) was removed from a trench located at University of Londrina. This column had the form of a prism that was moulded until reach the correct dimensions to be used at the measurement table, with $0.6 \mathrm{~m}$ height, $0.1 \mathrm{~m}$ width and $0.05 \mathrm{~m}$ thickness. It was involved in gauze and paraffined. Six soil columns were molded with the specifications given above, but only one soil column were analyzed in the water redistribution study, because the others were broken or exhibited water preferential flow between the soil and the paraffin layer in the infiltration process.

The gammagraphy was performed by fixing the soil column at the measurement table, moving it vertically and measuring gamma ray intensities in 
steps of $0.02 \mathrm{~m}$ until reached, $0.32 \mathrm{~m}$ depth. With the value of $\mu_{\mathrm{s}}$ obtained previously and using Equation (2), soil bulk density $\rho_{\mathrm{s}}$ for each soil depth was determined.

To perform the water infiltration, the top of the soil column was removed and two layers of filter paper, one layer of foam and five layers of filter paper were placed on the top to reduce the water flux on the soil surface and to control the infiltration speed. A sheet of water on soil surface with $0.01 \mathrm{~m}$ height was maintained during the whole infiltration process. The water was allowed to infiltrate the soil surface under atmospheric pressure. During the infiltration process, the wetting front progress and soil water contents were followed until saturation was achieved. After saturation down to the first half of the column, water supply was disconnected and water was left to drain naturally to the second half of the column.
Evaporation losses were prevented sealing the top of the soil column. Soil water content was measured in steps of $0.02 \mathrm{~m}$, during 22 days $(1.9 \mathrm{x}$ $\left.10^{6} \mathrm{~s}\right)$ after infiltration ended. Water content values $\theta(z, t)$ were calculated using Equation (3). With the water content profiles, the hydraulic conductivity $\mathrm{K}(\theta)$ was calculated using Equation (5).

\section{RESULTS AND DISCUSSION}

Table 1 showed the measured values of the water mass attenuation which was in good agreement with the value obtained by Oliveira (1991), with some discording of the measured values by Ferraz (1974) and Appoloni and Rios (1994), and in good agreement with theoretical value calculated whit the Win XCOM code (Gerward et al. 2001).

Table 1 - Values of the water mass attenuation coefficient.

\begin{tabular}{ll}
\hline \multicolumn{1}{c}{ authors } & \multicolumn{1}{c}{$\left.\boldsymbol{\mu}_{w} \mathbf{~ ( m}^{\mathbf{2}} \mathbf{k g}^{\mathbf{- 1}}\right)$} \\
\hline Measured in this work & $0.02016 \pm 0.00002$ \\
Oliveira (1991) & $0.0200 \pm 0.0002$ \\
Ferraz (1974) & $0.0200 \pm 0.0002$ \\
Appoloni and Rios (1994) & $0.0267 \pm 0.0001$ \\
WinXCOM & 0.0207 \\
\hline
\end{tabular}

The measured value for the mass attenuation coefficient for the LRd soil was:

$$
\mu_{\mathrm{s}}=0.4114 \pm 0.0045\left(\mathrm{~m}^{2} \mathrm{~kg}^{-1}\right) \text {. }
$$

The obtained value for the initial volumetric water content $\theta_{0}$ was:

$$
\theta_{0}=0.2230 \pm 0.0003\left(\mathrm{~m}^{3} \mathrm{~m}^{-3}\right) \text {. }
$$

Fig. 3 presented a plot of bulk soil density $\left(\rho_{\mathrm{s}}\right)$ versus depth (z), which showed a good homogeneity related to the depth. The uncertainties were determined performing error propagation in Equation (2).

Figs. 4 and 5 show the plots of water content $(\theta)$ as a function of time ( $\mathrm{t}$ ) for the levels $\mathrm{z}=0.08$ and $\mathrm{z}=0.20 \mathrm{~m}$, respectively. The uncertainties in the water content were calculated performing error propagation in Equation (3), were typically around $\pm 10 \%$. A water content decrease was noted as the time passed, which was a characteristic of the water drainage process. 


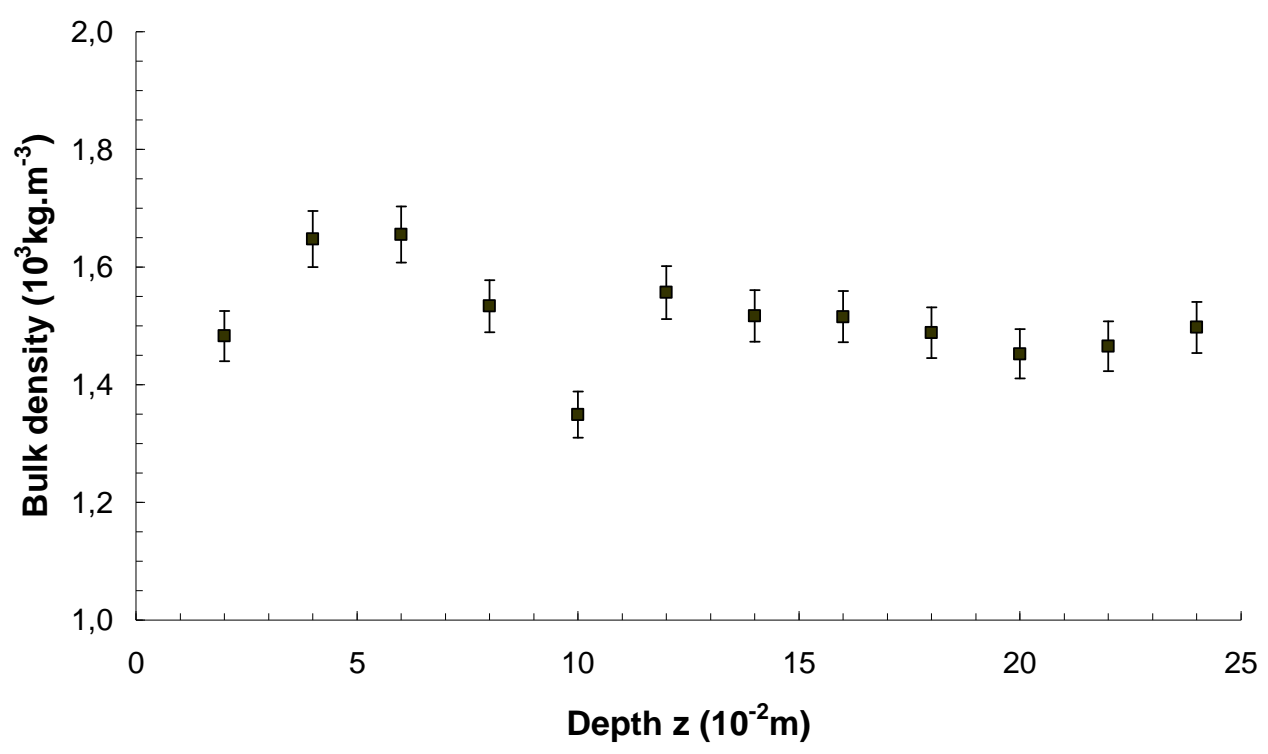

Figure 3 - Soil Column Densitometry.

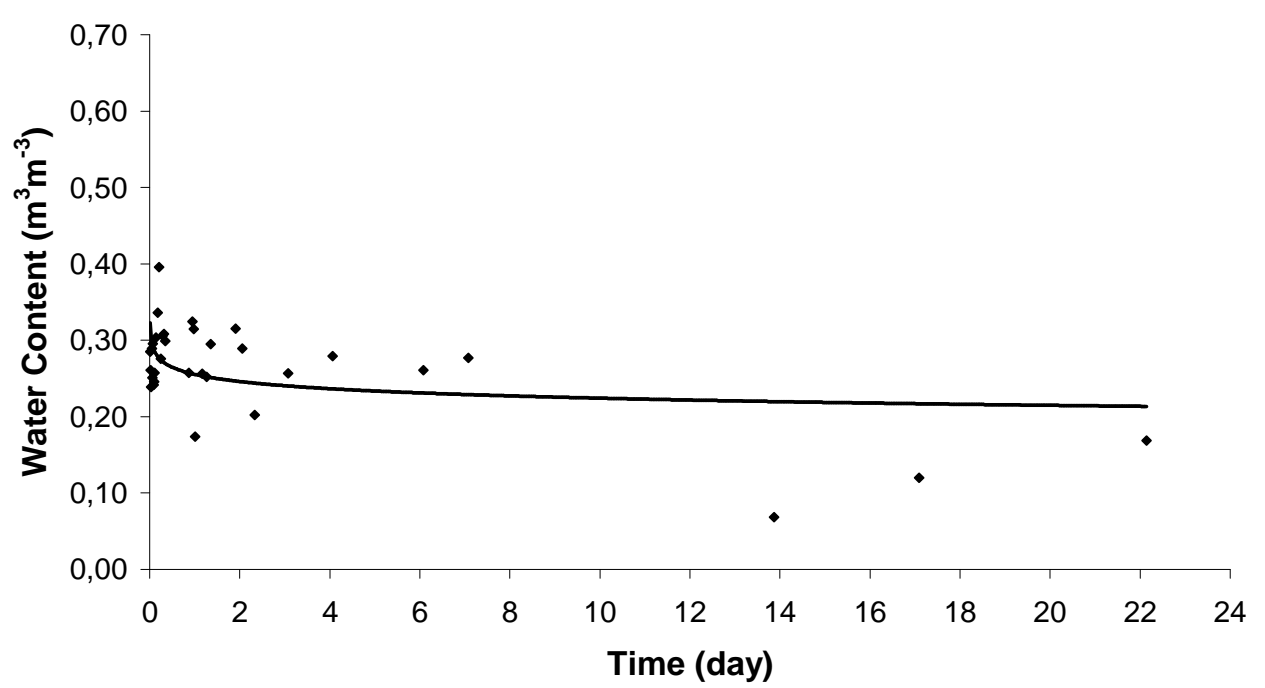

Figure 4 - Water Redistribution for $\mathrm{z}=0.08 \mathrm{~m}$. 


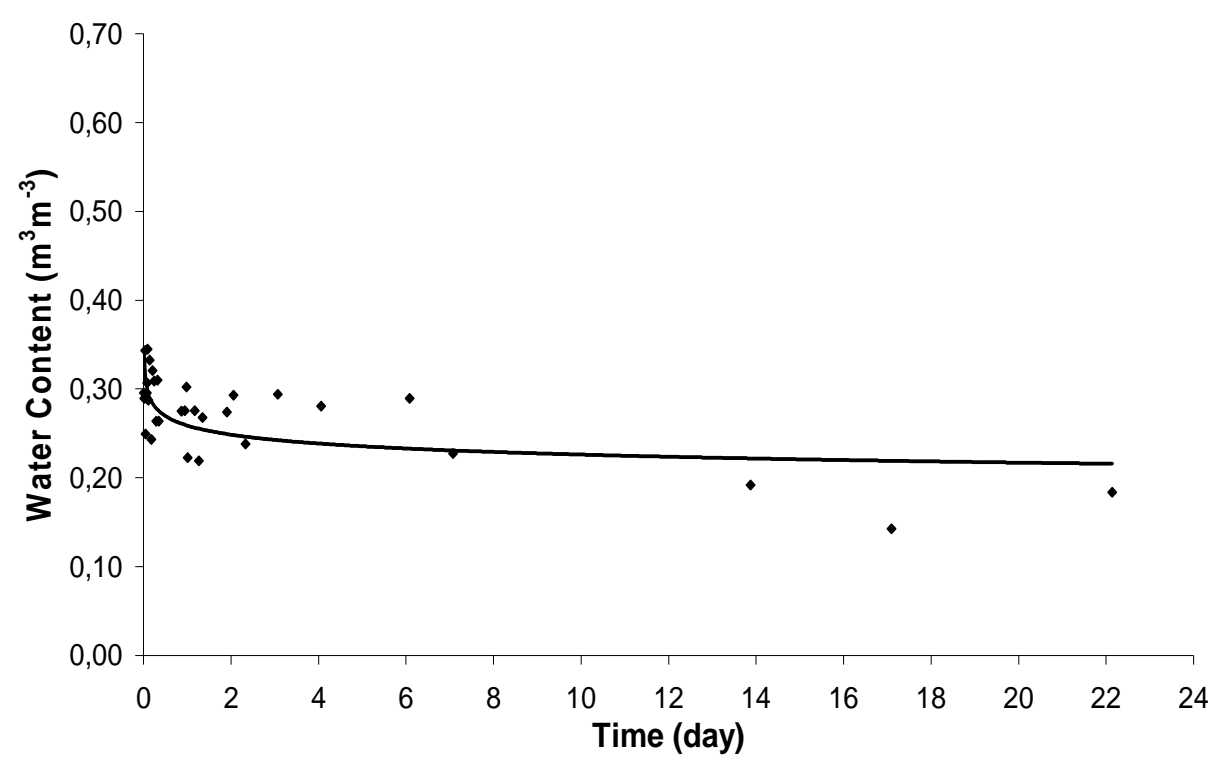

Figure 5 - Water Redistribution for $\mathrm{z}=0.20 \mathrm{~m}$.

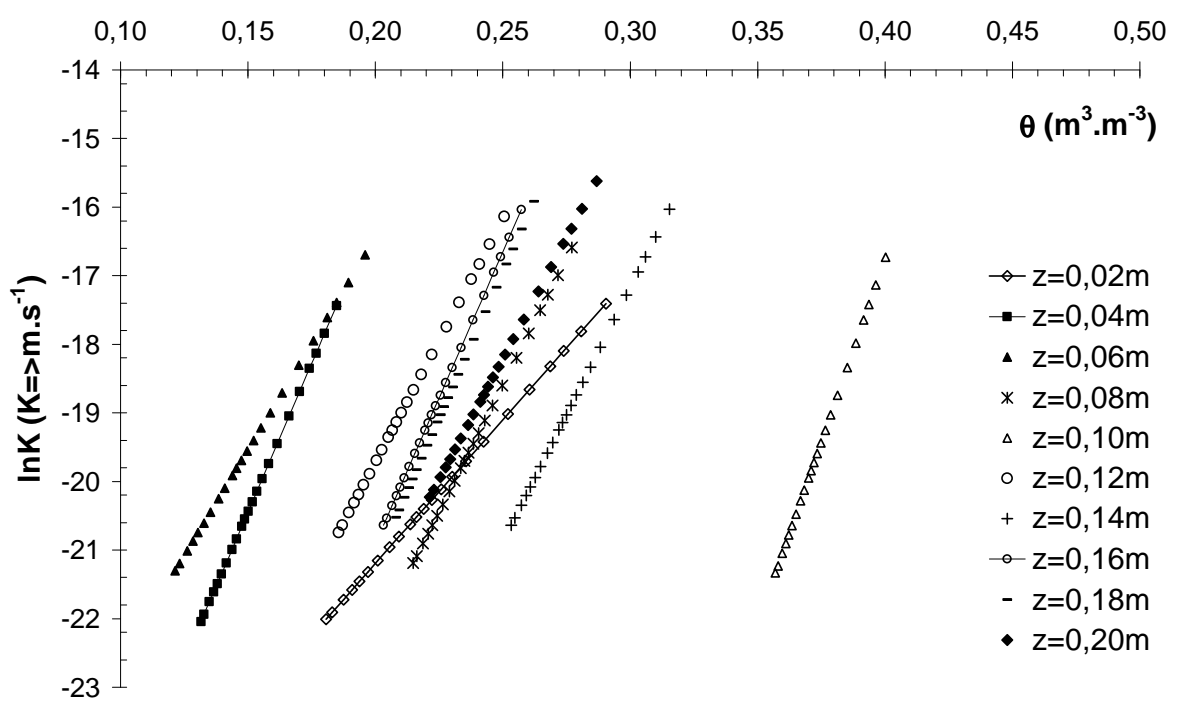

Figure $6-\ln \mathrm{K}\left(\mathrm{K}=>\mathrm{m} \mathrm{s}^{-1}\right)$ and water content $\theta\left(\mathrm{m}^{3} \mathrm{~m}^{-3}\right)$.

A linear regression fit to a straight line $\theta=a \ln t+$ b was applied to the experimental data, where a and $\mathrm{b}$ were constants adjusted using techniques to minimize the deviations. Table 2 shows the values of $a, b$ and $r$ (correlation coefficient) of the fit for each measured level, with time in seconds.
Fig. 6 shows the plots of $\ln K(\theta)$ versus $\theta$ from $\mathrm{z}=0.02 \mathrm{~m}$ to $\mathrm{z}=0.20 \mathrm{~m}$ for $\mathrm{LRd}$ undisturbed soil column. This showed the general behavior of increasing hydraulic conductivity related to the depth, superimposed with locally irregular pattern due to the non-homogeneity of the undisturbed soil sample. 
Table 3 showed the values of $\mathrm{K}_{\mathrm{s}}$ and $\gamma$ that were the saturated hydraulic conductivity and the slope parameter respectively, obtained with the method of Sisson et al. (1980) using Equation (4) for all the soil column depths $(0.02 \mathrm{~m} \leq \mathrm{z} \leq 0.20 \mathrm{~m})$. With these values, the hydraulic conductivity $K(\theta)$ could be calculated for each depth.

Table 2 - Values of the $a, b$ of equation $\theta=a \ln t+b$ and correlation coefficients $r$.

\begin{tabular}{cccccc}
\hline $\mathrm{z}(\mathrm{m})$ & 0.02 & 0.04 & 0.06 & 0.08 & 0.10 \\
\hline $\mathrm{a}$ & -0.024 & -0.012 & -0.016 & -0.014 & -0.009 \\
$\mathrm{~b}$ & 0.523 & 0.297 & 0.354 & 0.409 & 0.492 \\
$\mathrm{r}$ & -0.673 & -0.415 & -0.484 & -0.439 & -0.287 \\
\hline $\mathrm{z}(\mathrm{m})$ & 0.12 & 0.14 & 0.16 & 0.18 & 0.20 \\
\hline $\mathrm{a}$ & -0.014 & -0.013 & -0.012 & -0.012 & -0.014 \\
$\mathrm{~b}$ & 0.388 & 0.447 & 0.372 & 0.377 & 0.425 \\
$\mathrm{r}$ & -0.510 & -0.272 & -0.467 & -0.438 & -0.636 \\
\hline
\end{tabular}

Table 3 - Values of saturated Hydraulic Conductivity $\mathrm{K}_{\mathrm{s}}$ and slope parameter $\gamma$ of equation (5), and depths $\mathrm{z}$ in soil column.

\begin{tabular}{cccccc}
\hline $\mathrm{z}(\mathrm{m})$ & 0.02 & 0.04 & 0.06 & 0.08 & 0.10 \\
\hline $\begin{array}{c}\mathrm{Ks} \\
\left(\mathrm{x} 10^{-6} \mathrm{~m} \cdot \mathrm{s}^{-1}\right)\end{array}$ & 7.953 & 7.698 & 16.176 & 18.026 & 15.646 \\
$\gamma$ & 41.915 & 86.605 & 61.820 & 73.969 & 106.525 \\
\hline $\mathrm{z}(\mathrm{m})$ & 0.12 & 0.14 & 0.16 & 0.18 & 0.20 \\
\hline $\begin{array}{c}\mathrm{Ks} \\
\left(\mathrm{x} 10^{-6} \mathrm{~m} \cdot \mathrm{s}^{-1}\right)\end{array}$ & 28.239 & 31.453 & 31.320 & 35.220 & 47.328 \\
$\gamma$ & 70.824 & 36.179 & 85.142 & 85.179 & 70.430 \\
\hline
\end{tabular}

For LRd disturbed soil columns (Portezan Filho, 1997), it was observed that: $K_{s}$ values ranged from 5.4 to $67.5\left(\times 10^{-6} \mathrm{~m} \mathrm{~s}^{-1}\right)$ for one soil column, and from 5.6 to $62.0\left(\times 10^{-6} \mathrm{~m} \mathrm{~s}^{-1}\right)$ for the another soil column; $\gamma$ values ranged from 46.9 to 89.7 for the first soil column, and from 52.6 to 72.1 for the second one. The investigated undisturbed LRd soil column had a different range of values for these parameters: $\mathrm{K}_{\mathrm{s}}$ ranged from 7.7 to $47.3\left(\mathrm{x} 10^{-6} \mathrm{~m} \mathrm{~s}^{-}\right.$ ${ }^{1}$ ), and $\gamma$ ranged from 36.1 to 106.5. Hence, compared to the disturbed LRd soil column, the undisturbed column presented a $\mathrm{K}_{\mathrm{s}}$ value interval $30 \%$ smaller and a $\gamma$ value average interval $165 \%$ higher. There $K_{s}$ and $\gamma$ parameters values of the undisturbed soil indicated a very different water behavior in the real soil, compared to what can be concluded based on disturbed soil data. There was no $K(\theta)$ data in the literature for undisturbed soil columns.

\section{CONCLUSION}

Employing the non destructive gamma ray transmission methodology, the hydraulic conductivity $K(\theta)$ function of a undisturbed LRd soil column was measured. The results obtained for the $K(\theta)$ showed an increasing behavior of the hydraulic conductivity related to the depth in the undisturbed soil column. The $\mathrm{K}_{\mathrm{s}}$ and $\gamma$ values implied in a very different $K(\theta)$ function compared to the $\mathrm{K}(\theta)$ function obtained from disturbed column soil data as obtained by Portezan (1997).

\section{RESUMO}

O estudo da condutividade hidráulica para solos 
não saturados é essencial quando aplicado às situações relacionadas à irrigação, drenagem e transporte de nutrientes no solo, é uma importante propriedade para desenvolvimentos de culturas agrícolas. Este trabalho tem o objetivo de determinar a função Condutividade Hidráulica $\mathrm{K}(\theta)$, em diferentes níveis $\mathrm{z}$ de profundidade, em colunas de solo indeformado, utilizando a transmissão de raios gama aplicada ao método de Sisson. Os resultados indicam um comportamento crescente para $K(\theta)$ e uma densidade de solo homogênea, ambos em relação ao aumento da profundidade. A metodologia de transmissão de raios gama mostrou resultados bastante satisfatórios na determinação da condutividade hidráulica em colunas de solo indeformado, além de ser muito confiável e não destrutivo.

\section{REFERENCES}

Appoloni, C. R.; Rios, E. A. (1994), Mass attenuation coefficients of brazilian soils in the range 10-1450 $\mathrm{keV}$. Applied Radiation Isotopes, 45, 287-291

Corey, J. C.; Peterson, S. F.; Wakat, M.A. (1971), Measurement of attenuation of ${ }^{137} \mathrm{Cs}$ and ${ }^{241} \mathrm{Am}$ gamma rays for soil density and water content determinations. Soil Science Society of American Proceedings, 35, 215-219

Falleiros, M. C.; Portezan, O.; Oliveira, J. C. M.; Bacchi, O. O. S.; Reichardt, K. (1998), Spatial and temporal variability of soil hydraulic conductivity in relation to soil water redistribution, using an exponential model. Soil and Tillage Research, 45, 279-285

Ferguson, H.; Gardner, W. H.; (1962), Water content measurement in soil columns by gamma ray absortion. Soil Science Society of American Proceedings, 5, 390-398

Ferraz, E. S. B. (1974), Determinação simultânea de densidade e umidade de solos por atenuação de raios gama do ${ }^{137} \mathrm{Cs} \mathrm{e}{ }^{241} \mathrm{Am}$. PhD Thesis, ESALQ/USP, Piracicaba, Brazil

Gardner, W. H.; Calissendorff, C. (1967), Gamma-ray and neutron attenuation in measurement of soil bulk density and water content. Paper presented at InIsotope and radiation techniques in soil physics and irrigation studies. Vienna, IAEA, 101-113

Gerward, N. Guilbert, K. B. Jensen And Levring. H. (2001), X ray absorption in matter. Reengineering XCOM. Radiation Physics and Chemistry, 60, 23-24

Hillel, D.; Krentos, V. D.; Stylianou, Y. (1972), Procedure and test of an internal drainage method for measuring soil hydraulic characteristics in situ. Soil Science, 114, 395-400
Libardi, P. L.; Reichardt, K.; Nielsen, D. R.; Biggan, J. W. (1980), Simple field methods for estimating soil hydraulic conductivity. Soil Science Society American Journal, 44, 3-7

Nofziger, D. L. (1978), Errors in gamma-ray measurement of water content and bulk density in non uniform soils. Soil Science Society American Journal, 42, 845-850

Oliveira, J. C. M. (1991), Determinação de parâmetros do solo durante a infiltração horizontal e redistribuição da água por atenuação de raios gama e tensiometria. PhD Thesis, CENAQ/USP, Piracicaba, Brazil

Portezan Filho, O. (1997), Análise crítica da determinação da condutividade hidráulica do solo utilizando atenuação de radiação gama monoenergética. PhD Thesis, IPEN/USP, São Paulo, Brazil

Reginato, R. J.; Van Bavel, C. H. M. (1964), Soil water measurement with gamma attenuation. Soil Science Society of American Proceedings, 28, 721-724

Reichardt, K. (1965) Uso da radiação gama na determinação da umidade e densidade do solo. $\mathrm{PhD}$ Thesis, ESALQ/USP, Piracicaba, Brazil

Sisson, J. B.; Ferguson, A. H.; Van Genuchten, M. T. H. (1980), Simple method for predicting drainage from field plots. Soil Science Society American Journal, 44, 1147-1152

Souza, A. D. B.; Saito, H.; Appoloni, C. R., Coimbra, M. M.; Parreira, P. S. (1991), Uptake, medida dos parâmetros da infiltração vertical e redistribuição da água nos solos LRd e LEa por transmissão de raios gama. Paper presented at $1^{\circ}$ Encontro Nacional de Aplicações Nucleares, 27-30, Recife

Vaz, C. M. P.; Oliveira, J. C. M. ; Reichardt, K.; Crestana, S.; Cruvinel, P. E.; Bacchi, O. O. (1992), S. Soil mechanical analysis through gamma ray attenuation. Soil Technology, 5, 319-325

Received: May 04, 2005; Revised: June 01, 2006; Accepted: October 20, 2006. 